\title{
The Impact of Promotional Tools on Consumer Buying Behavior: A Study from Pakistan
}

\author{
Aurangzeb Mughal \\ Student, Department of Management Sciences \\ The islamia university of Bahawalpur \\ Email: mughal.bba3rd@gmail.com \\ Asif Mehmood \\ Student, Department of Management Sciences \\ The islamia university of Bahawalpur \\ Email: asifjoiyaiub@gmail.com
}

\author{
AmmarMohi-ud-deen \\ Student, Department of Management Sciences \\ The islamia university of Bahawalpur \\ Email: neutron.dreamz@gmail.com
}

Bilal Ahmad

Student, Department of Management Sciences

The islamia university of Bahawalpur

Email: bilal.bba3rd@gmail.com

Accepted: September 22, 2014

Doi:10.5296/ jpag.v4i3.6680 URL: http://dx.doi.org/10.5296/ jpag.v4i3.6680

\begin{abstract}
The main purpose of this research was to investigate the effect of sales promotion and natural environment that is casual factor in consumer buying behavior. The survey found that there
\end{abstract}


was an insignificant relationship between coupons and buying behavior. On the other hand the buy-one-get-one free, Physical surrounding has a significant relationship with the purchasing behavior. The consequences of this research will help marketers to recognize the most excellent kind of promotional tools that significantly influence the purchasing behavior of consumers. Traders can develop their business plan more effectively through the results of this study and plans help entrepreneurs and traders to gain a competitive benefit over their competitors and enable businesses to gain maximum profit.

Keywords: Attitude towards mobile advertisement, Permission, Purchase intension, Advertising value

\section{Introduction}

Promotion is a tool that is used by the retailers or manufacturer to invite consumers to purchase more. The results which we get by the sales promotion is the use of high amount of reserve, inviting a lot of new customers and additional increase in sales. Although all the marketing activities are linked with sales promotions that gives outcome in growing consumer purchases and improving intermediaries or retailer's efficiency and co-operation. According to Withier \& Moore (2007) many purchase situations are so usual that shoppers conduct a very minor cognitive activity. Actually, it is hard to stimulate behavior such as brand switching or increasing in the number of units purchased. The rising interest in the use of sales promotion as a marketing strategy has resulted in a surprising growth of research in this area. For instance, there is a huge body of literature on consumer response due to sales promotions. The increasing interest in the use of sales promotion as a marketing tactic has resulted in an unusual growth of research in this area.

Sales promotions consist of a huge variety of temporary planned promotion tools which plan is generating a preferred response from the consumer (Gilbert and Jackaria, 2002). One of sales promotion tools benefit is that it can encourage the consumers to think and evaluate brand and purchase opportunities. Hence, different types of promotion tools and promotion strategies are utilized by the marketers so that they can know consumer first choice and boost their sales. This reality indicates that many consumers are easily temped when they recognize the term Sale Promotion. According to Gilbert (1999), other than price lessening, coupons or refund given by the retailers as well as other marketing tools such as free sample and buy-one-get-one-free were found to be inducing consumer buy more then they expect. Different kinds of promotion tactics are used by the sellers to attract the customers and increase their sales. The earlier studies has shows that framing of advertising messages and presentation of price information influence the consumer's views about prices and their willingness to purchase (Das, 1992; Sinha and Smith, 2000 and Sinha et al., 1999).

The core purpose of this research paper is to study the impact of different sales promotion tools on consumer buying behavior. Hence, the Research on promotional tools is certainly vital to recognize the most influencing tools to compete with its competitors. The purpose of research is to study closely the fondness of customers on a variety of promotional tools. With 
the help of this information, the marketer and retailers could well plan their resources to get the highest profit. This research aims to examine the partiality of consumer on different promotional tools, marketers and retailers will able to conscious of the consumer buying behavior, so that they can make use of the right and the most successful promotion techniques to catch the attention of the customer. The usual promotion tools includes samples, price discounts, buy-one-get-one-free, Coupons, in-pack premiums, price offs and so on. But In this study, we will discuss the impact of buy one get one free, price discounts, coupons and physical surroundings on the consumer buying behavior. The physical surrounding is a situational factor, which effect consumers buying behavior. These promotional techniques affect the consumer buying behavior during the shopping. Earlier research has revealed that these factors have important relationship with consumer's buying behavior. The impacts of these tools differ from country to country. So our study can produce different results from the earlier study.

This paper is prepared in following way, Section 1: Introduction, Section: 2 present the relative literature review of sales promotion techniques like, Buy-one-get-one-free, Coupons, Physical surroundings and Buying behavior. Section:3 of the study describes the methodology which contains sample and data analysis technique, Quantitative analysis and experimental outcomes. In discussion section outcomes are debated and sanctions are offered with study restrictions. As a final point, next and last section draws conclusions of research by the planned approaching.

\section{Literature Review}

\section{Promotion Effects on Consumer Buying Behavior}

Promotion is a utensil that used by the retailers or manufacturer to attract consumers and purchase more or tries a service or product. The result of the sales promotion is the used of high quantity stock, appealing many new customers and more increase in sales. Chandon, Wansink, and Laurent (2000) indicated that sales promotion may be gorgeous for well promotion prone consumers for reasons beyond price savings. Many consumers change brands so that they could receive greater deals that replicate and build up their smart buyer self-perception, and these consumers are favorably promotion prone, these consumers make an attempt to try a new product or service that have been promoted. For an example, decrease in price for a limited period to attract more a new consumer is refers to as price promotion. Sales promotion means any activity that is utilize by the producer to give confidence the trade (retailer, wholesaler, or network associates) as well as make customers to purchase a brand and boost up sales force to assertively sell it. The term sale promotion refers to several types of selling incentives and methods concave to yield immediate sales effects (Totten \& Block, 1994). 


\section{Attitude towards Buy-One-Get-One-Free}

"Buy one get one free" is one of promotion method of sales promotion in which an extra product is offered to the customers at normal price but with greater improve in package. The customers could easily influence to purchase the produce because there is no condition of any additional price and it should be more valued by the customer to perceived (Sinha\& Smith, 2000). Gardener and Trivedi (1998) have written that larger size of package and proper advertising of the product help to make the promotion more attractive. When the extra produce is contain without any additional price, the customer could convinced to purchase the produce if the consumers has sense that their money can be kept with this deal. The bonus packages inspire the consumers to purchase the produce (Percy, Rossiter, and Elliott, 2001). The bonus packs liked by producers or manufacturers because it should increase the product trial, switching a product and forcing stores to stock product. According to Li, Sun \& Wang (2007), this technique of promotion would be very useful to manufacturer because it should help the retailers to clear the stock more hastily as contrast price promotion. Therefore, we can say that:

H1. "Buy-One-Get-One-Free" has a positive impact on consumer buying behavior during sale promotion.

\section{Attitude towards Coupons}

The word of coupon advertisings is related to those customers who gained vouchers are eligible to get allowance on the products at its usual price (Ndubisi\& Chew, 2006). Coupons are defined as vouchers or certificates, which help consumers to a price reduction on a specific product (Fill, 2002). The value of discount or price cut is set and the coupon must be presented when customer purchases product. According to Cook (2003), coupons are easily understood by the customer and can be extremely useful for trial purchase. Coupon is a confirmed method by which producers can communicate with customers and it can be used as a strong brand-switching tool. Gardener and Trivedi (1998) reported that for many years as a means of presenting the customer a one-time reduction in price and construct brand consciousness and loyalty, for this purpose coupons have been used as key promotion tools. Actually, coupons have increased brand switching and influence purchases, indicating that consumers are influenced by the discount declared in the coupon. In the previous study it was found that six months after getting one of these coupon proposals, customers were between two and five times more likely to buy and use the promoted brand in the past than were a control group of a like customers who had not acquired coupon. Customers who got the coupon deal were also double as possible to show that they would purchase the promoted brand in the future. Wayne (2002) in a new consumer research on three recent coupon programs showed that the promoted brands gained incremental sales through enlarged trial and succeeding non-coupon purchases. They also wrote that coupon advertising was between the least used and not accepted marketing tools by customers. So we can hypothesize as:

H2. Coupons have a positive relationship with Consumer buying behavior during sales 
promotions.

\section{Attitude towards Physical Surroundings}

Now a day's Shopping centers had different kinds of store and most of countries clutch similar sales advertisings yearly. Throughout the sales advertising, retail shops frequently changes in physical surrounding with various kinds of music, décor and sales discount ranging from 25 to 75 per cent. This friendly environment transform would motivate and influence consumers purchasing behavior. It is frequent to watch that shopping malls lean to put up amazing physical surrounding as extrinsic value to draw customers to the mall and stores. In addition, the picture of the shopping Centre encourages consumer store condescending (Sit et al., 2003). This "front line" picture attraction is useful to retail stores. The elements that are include in physical surrounding such as arrangement, interior design and decoration, lighting, music, smell and cleanliness (Baker, 1987). It would be observed that during festive period like Christmas, individual footwear stores' sales persons decent in festive clothing adds glamour its environment. Other researches also shows optimistic relations by purchasers to the physical surroundings, which lean to encourage their useful requirements (Kim, 2002 and Keng et al., 2007). In the next purchase, consumers frequently try to form an assessment of their past mall and store experiences on the physical surroundings and services provide. These factors jointly persuade customer quality hopes (Baker, 1987) of a shopping mall and we hypothesized as:

H3. There is a positive relationship between physical surroundings and consumers buying behavior during sales promotions. 


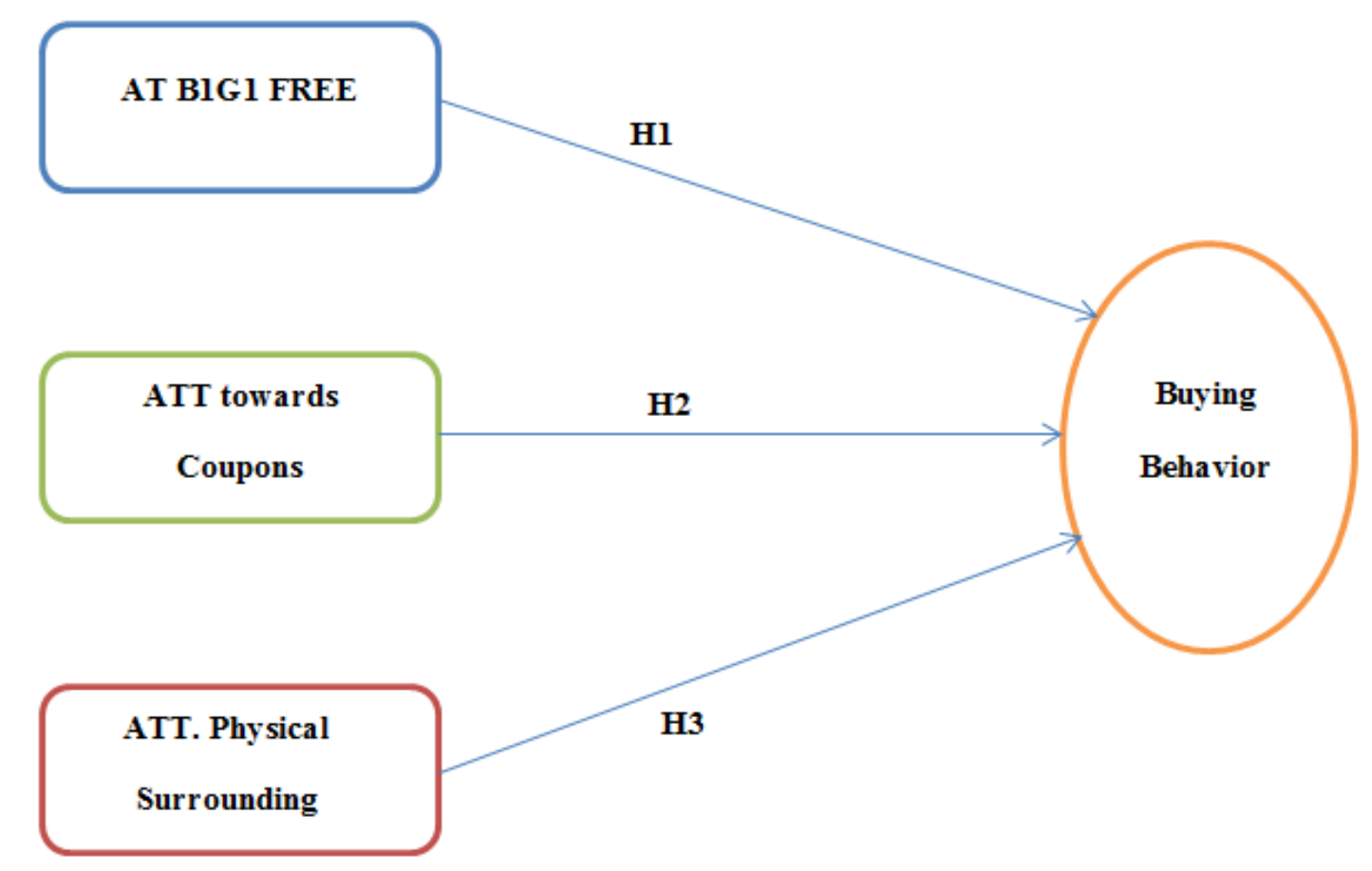

\section{Research Methodology}

The research, which is used in this study, is descriptive in its nature. It can be explained by particular situation, telling some sort of things or some sort of noticeable facts. Research that explains the present situation instead of interpreting and making judgments is descriptive research (Creswell, 1994). The core purpose of descriptive research is to establishing the accurateness of developed hypothesis that reflect the present position. This kind of research gives knowledge about the current scenario and concentrate on past or present for an instance in a community quality of life or customer attitude toward any marketing activity (Kumar, 2005). The pilot study has been done before conducting the actual research. The core purpose of pilot research was to calculate the reliability of the questionnaire items that were utilized in this research. A total 200 students were selected to make sure that items of the questionnaire were understandable without difficulty by the person who answers that questionnaire. Throughout this study the researcher self-assurance has developed and he make sure that questionnaire that was used was healthy for this research.

\section{Sample and Data Analysis}

About 200 respondents were asked to participate in self-administrative study in order to gather the data for understanding the condition about the consumer buying behavior. The people for the current research are common people, students or any customers who have 
experience in buying some kind of products. The non-probability sampling method utilizes in the current research. The non-probability sampling is very ease because in this sampling technique information can be collecting from the relevant sample or the unit of the study that are conveniently available (Zikmund, 1997). The convenience sampling is used for collecting a large number of fulfilled surveys quickly and inside limited cost.

The sample members possess the two main qualifications for participating in self-administrative surveys. First, is that all respondents were well educated and secondly they were purchasing different goods and services and we have observed their experiences. The three main clusters were targeted to gather the sample data like, working professionals, university students and businesspersons. According to the Brown (2007), buying behavior means that decision making process that we had observed.

\section{Questionnaire and Scales}

The questionnaire is used as instrument of research in this current research. The questionnaire contains two main portions. The first part contains the background of a person who answers the questionnaire; the second part shows the consciousness with respects to a variety of promotion tools and purchasing behavior of persons who answer the questionnaire. In the first portion every person who answer the questionnaire were told to provide the information about age, gender, education, monthly income, and his or her status. In the second portion of survey questionnaire thirty three items were selected. To measure the each variable five items were used and eight items were used to calculate the purchaser buying behavior. Buy-one get-one-free, coupon, and one situational factor that physical surrounding has tested. In this study liker scales five point were used, 1 for (strongly agree), and 5 for (strongly disagree). This scale is adopted from the Bakewell and Mitchell (2003), David Yoon Kin tong, Kim Piew Lai, Xue La Tong (2012) study. To analyze the data the Statistical Package for Social Science (SPSS) version 17.0 was used.

\section{Procedure}

The questionnaire was distributed between 200 respondents at different areas in Bahawalpur. The respondents were chosen based on above mentioned criteria. The ambition of the research and questions were comprehensively explained to the respondents earlier than providing the questionnaire so that they can answer the questionnaire with no trouble through related responses. A total of 180 questionnaires were selected and other questionnaires were not integrated in the further analysis due to unfinished and worthless responses from the respondents. After collecting the entire questionnaires, these questionnaires were coded and then entered into SPSS for regression analysis.

\section{Reliability Analysis}

Overall Cronbach's alpha of questionnaire items that is more than acceptable and recommended value 0.50 by Nunnally (1970) and 0.60 by Moss et al., (1998). The Table 2 shows that all 22 items were reliable and valid to measure the opinion of consumers towards Buying Behavior. 
Table-1 Reliability of Questionnaire and Scales

\begin{tabular}{|l|l|l|}
\hline Scales & Items & Cronbach's Alpha \\
\hline $\begin{array}{l}\text { Attitude towards } \\
\text { Buy-One-Get-One-fr } \\
\text { ee }\end{array}$ & $\mathbf{5}$ & .715 \\
\hline $\begin{array}{l}\text { Attitude towards } \\
\text { coupons }\end{array}$ & 5 & .797 \\
\hline $\begin{array}{l}\text { Physical } \\
\text { surroundings }\end{array}$ & 5 & .737 \\
\hline Buying Behavior & 8 & .639 \\
\hline
\end{tabular}

\section{Result And Analysis}

Profile of the respondents: The utilizable questionnaires that were returned by respondent were 180 Out of 200 questionnaires, the answer provides by the male respondents were $50 \%$ and female were 50\%. Their Personal and demographic information such as gender, age, income, education level and status are presented in the following table.

Table 4: Profile of the Respondents

\begin{tabular}{|l|l|l|l|}
\hline Variable & Category & Frequency & Percentage \\
\hline Gender & Male & 90 & 50.0 \\
Female & 90 & 50.0 \\
\hline \multirow{5}{*}{ Age } & 15-20 Years & 60 & 33.3 \\
20-25 Years & 79 & 43.9 \\
25-30 Years & 16 & 8.9 \\
$30-35$ Years & 7 & 3.9 \\
35-40 Years & 6 & 3.3 \\
& Above 40 Years & 2 & 6.7 \\
\hline & Below 15000 & 81 & 45.0 \\
\hline
\end{tabular}




\begin{tabular}{|l|l|l|l|}
\hline Income & $15000-25000$ & 30 & 16.7 \\
$25000-35000$ & 19 & 10.6 \\
$35000-45000$ & 13 & 7.2 \\
$45000-55000$ & 15 & 8.3 \\
Above 55000 & 22 & 12.2 \\
\hline Education & Matriculation & 11 & 6.1 \\
& Inter & 21 & 11.7 \\
Bachelor & 89 & 49.4 \\
Master & 29 & 16.1 \\
& MS/ M. Phil & 21 & 11.7 \\
& PHD & 9 & 5.0 \\
\hline
\end{tabular}

\section{Hypothesis Testing}

Regression analysis techniques were applied to measure or to build the relationship among the promotional variable by using SPSS 17.0. The results of the regression analysis shows in Table 4 that were used to calculate the relations among the promotional tools their named as, buy-one-get-one-free, coupons, and physical surroundings and buying behavior.

\section{Attitude towards Buy-One-Get-One-Free and Buying Behavior}

The regression analysis of the study shows that the variable buy-one-get-one-free have significant positive relationship with buying behavior $(\beta=.414, \mathrm{p}=.000)$ and shows that buy-one-get-one-free has strong positive impact on the consumer buying behavior.

\section{Attitude towards Coupons and Buying Behavior}

Regression estimates results shows that attitude towards coupons has significant relationship between these two variables $(\beta=-0.063, \mathrm{p} .450)$. Based on these results, we conclude that research show negative insignificant relationship with buying behavior.

\section{Physical Surroundings and Buying Behavior}

According to the results physical surroundings also has significant strong positive impact on the buying behavior of consumer $(\beta=0.161, p=0.035)$. So the result of this study shows that the environment of the retail shop also important factor which can affect the consumers purchase intention and has strong significant relationship with buying behavior of consumers. 
Table 6: Regression Results

\begin{tabular}{|c|c|c|c|c|c|c|c|}
\hline Hypothesis & \multicolumn{2}{|c|}{ Model Variables } & Estimate/ $\beta$ & S.E & C.R & $\mathbf{P}$ & Results \\
\hline H1 & $\begin{array}{l}\text { Att. } \\
\text { BB }\end{array}$ & B1G1F & .414 & 0.067 & 4.089 & .000 & Supported \\
\hline $\mathrm{H} 2$ & $\begin{array}{l}\text { Att. } \\
\text { BB }\end{array}$ & $\overrightarrow{\text { Coupons }}$ & -.063 & 0.058 & .757 & .450 & NotSupported \\
\hline H3 & $\begin{array}{l}\text { Att.PS } \\
\text { BB }\end{array}$ & & 0.161 & 0.059 & 2.123 & 0.035 & Supported \\
\hline
\end{tabular}

Model

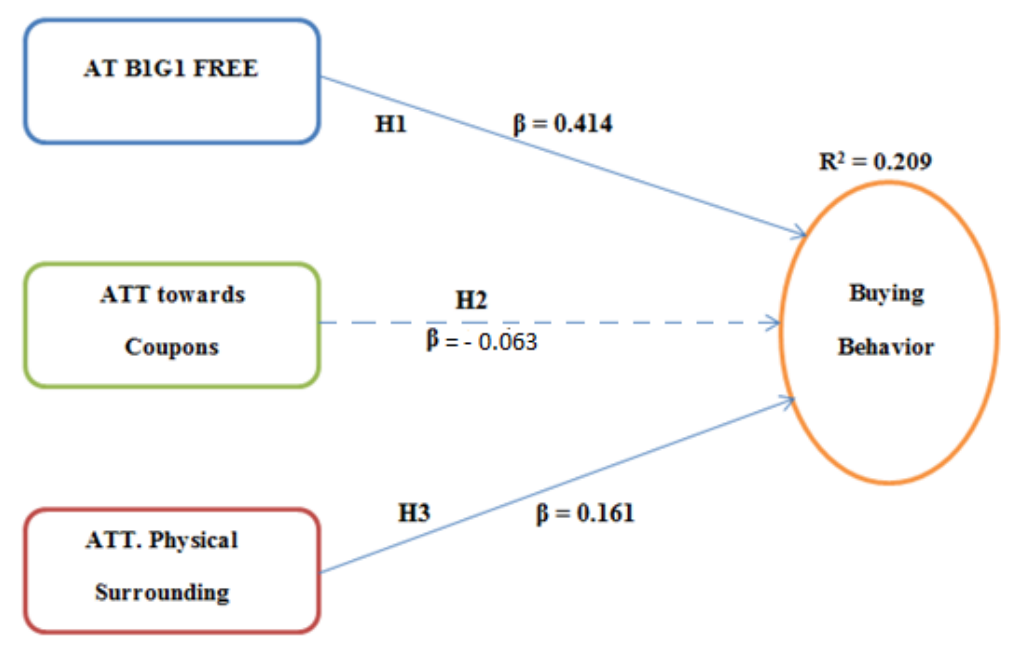

\section{Discussion}

The major objective of this research was to study the impact of different promotion techniques, which can affect the consumer buying behavior, and it can also be used by the businessmen to increase their sales and improve their business. For this purpose, we have taken four promotional tools and one situational factor, which can affect the consumer buying behavior. These tools are free sample, buy-one- get-one-free, and coupons. Physical Surroundings is a situational factor that can be used to measure the buying behavior of the consumer. The result of this learning gave some important knowledge about impact of promotion tools on consumer buying behavior. With respect to customer proneness to sale promotion, research found that Physical Surroundings and Buy-One-Get-One-Free and 
coupons played the greatest significant role in developing consumer-buying behavior. The above results show that, buy-one-get-one-free has significant relationship with the buying behavior $(\mathrm{t}=4.869, \mathrm{p}=0.000)$

Physical Surroundings also has an important situational factor which has a strong positive impact on buying behavior $(\mathrm{t}=2.123, \mathrm{p}=0.035)$ coupons have significant relationship with the buying behavior $(\mathrm{t}=0.757, \mathrm{p}=0.04)$ respectively.

The result of this study also explained that buy-one-get-one-free is significantly linked with consumer buying behavior, therefore the more the product has included at no extra cost, than it can influence customers to purchase products for test. It revealed that advertising instrument such as buy-one-get-one-free can appeal and persuade customer's favorable attitude on buying behavior. Therefore, it can be explained that buy-one-get-one-free is one of the essential element persuading buying behavior of customers, particularly in the repurchase of new product. The results of this research showed that there is major association at 5\% significance level among coupons and consumer buying behavior) results, awareness with coupons has significant positive effects on customer attitudes toward coupons.

Another main important factor, which is shown in this research, is physical surroundings. The results of this study estimate that the physical surrounding also significant relationship with buying behavior of consumer. In this research, shoppers were inquired about shops likings that contain interior decoration of shops, music, brightness, shopping in large retail shops and when the shopping mall is nicely in odors. The result of this study shows that buyers enjoy shopping in an environment with music and in large retail store as well as when the shopping mall is bright lightening. According to Alpert and Alpert, (2006); Keng et al., (2007) and Baker, (1987), the previous research have exposed that music has significant effect on listener's moods and buying behavior. It was found that neat and spacious atmosphere affect utilitarian shoppers' level of intention to patronize, time and money spent (Jin and Kim, 2003). The interior décor has significant impact on consumer buying behavior. Therefore, we can say that physical surroundings are very important during shopping by the consumers

\section{Implications}

This study has great worthy effects on theory. The structure gives new visions to understanding sales promotions tools and their influence on consumer buying behavior. Personal characteristic of the consumer are involved particularly in selecting and making purchase decision. From the findings, it was found that consumers pay great attentions on promotion and react clearly to the different marketing techniques that are promoted through the sales persons. The outcomes of this research have frequent effects that could be valuable for marketers, customers and future researchers. Since marketer's point of view, they can get best knowledge about the buying behavior of the consumer so that businesses can understand the need and wants of the prospective customers. Marketers can obtain data from this study that will facilitate them to get awareness about the buying behavior of the customers and it can also facilitate the marketers to use the most effective promotional techniques to attract customers. This research is very important for the organizations, because every organization wants to minimize their costs and maximize their profits. The concrete implications of this 
research lie initially in management's acknowledgment of sales promotion tactics that are pertinent to Pakistani customers. By offering the right promotional incentives, marketing strategies and their firms can increase sales by creating repeat buying behavior to their offering. So, the organizations should begin with and place large amount of money on those tools that are more attractive

\section{Limitations And Future Recommendations}

Although this research has taken vital steps to identify the factors that influence buying behavior, it also has certain limitations. Firstly, the limitation of the data prevents further exploration of the study. There was limit on age and only 180 respondents have contributed in this explore. These respondents were practically similar in age varieties since they were between 18 to 25 years old and represent early adulthood only. By the generated difference in the ages of the respondents, different results could be.

Secondly, upcoming researchers have more opportunity to do their research in improved situation and at various physical localities. Different environments always play a positive role that helps to affect respondent's behavior especially at place of work, shopping complex or malls and supermarkets. Related to this sample, functioning persons could act in a changed way. Besides, the individuals who do not have profession such as housewife and retire person may also behave differently because the understanding and experience of respondents towards the questions might influence their answers. Since this study was conduct in The Islamia university of Bahawalpur and different area of Bahawalpur Pakistan, it could not represent other people living in urban or rural areas where the quality of life is totally different. Finally, it recommended for the future researchers they include interview method in doing study specifically at the place where business transactions are happening. It will assist scholars to attain accurate info established on the respondents' fresh memory.

\section{Conclusion}

Sale promotion plays a essential role for the dealers and retailers in the marketing programs. Sales Promotion generates large revenues and by using promotional tools sales can be increased. Various promotional techniques are used by the marketers in order to offer customers an additional incentive to purchase their products and then promotion in classic means. This research supported by the research from Cuizon (2009) who stated that sales promotions are not only effective in attaining short-term sales as they are also more cost-effective compared to other included marketing communications tools such as advertising. The overall conclusion of this research is we found positive customers attitude towards various promotion tools on buying behavior. The study confirmed that consumers buying behavior can be motivated through various kinds of elements, including promotion techniques such as coupons, buy-one-get-one-free and physical surrounding. Furthermore, the structure offers new visions to understand that how different consumers respond to numerous promotion tools offered by marketers and their impacts on consumers buying behavior, which may be central for marketers in order to use perfect promoting strategies and promotional tools to promote products. 


\section{Macrothink \\ Journal of Public Administration and Governance \\ ISSN 2161-7104 \\ 2014, Vol. 4, No. 3}

\section{Reference}

Alpert, J. I. and Alpert, M. I. (2006) "Music influences on mood and purchase intentions" Psychology and Marketing, Vol. 7, No. 2, pp. 109-33.

Baker, J. (1987) "The role of environment in marketing service: the consumer perspective", in Czepeil, J.A., Congram, C.A. and Shanahan, J. (Eds), The Service Challenge: Integrating for Competitive Advantage, American Marketing Association, Chicago, IL, pp. 79-84

Bakewell, C., and Mitchell, V. W. (2003) "Generation Y Female Consumer Decision-Making Styles" International Journal of Retail and Distribution Management, Vol. 31, No. 2, pp. 95-106.

Banks, J., \&Moorthy, S. (1999) “A model of price promotion". International Journal of Industrial Organization, Vol. 17, pp. 371-398. Banks, P. (2003) Store was set to rage on Irelands Marketing Monthly. Vol. 14, No. 8, online, available at: http://www.marketing.ie/sep03/article4.htm.

Creswell, J.W. (1994) “Research Design: Qualitative \& Quantitative Approaches" London: SAGE Publications.

Chandon,P.Laurent, G. and Wansink, B (2000) "A benefit congruency framework of sales promotion effectiveness” Journal of Marketing. Vol. 64, No. 4, pp. 65-81

Gardener,E and Trivedi, M. (1998) "A communication framework to evaluate sale promotion strategies" Journal of Advertising Research. Vol. 38, No. 3, pp. 67-71.

Gilbert, D. (1999) Retail Marketing Management. Harlow: Prentice Hall.

Gilbert, D.C. and Jackaria, N. (2002) "The efficacy of sales promotions in UK supermarkets: A consumer view" International Journal of Retail \& Distribution Management, Vol. 30, No. 6, pp. 315-322.

Das, P.R. (1992) "Semantic cues and buyer evaluation of promotional communication", in Leone, R.P. and Kumar, V. (Eds), Enhancing Knowledge Development in Marketing, American Marketing Association, Chicago, IL, pp. 12-17.

Kim, Y. K. (2002) "Consumer value: an application to mall and internet shopping", International Journal of Retail \& Distribution Management, Vol. 30, No. 12, pp. 595-602.

Totten, J.C. and Block, M.P. (1994) "Analyzing Sales Promotion: Text \& Cases: How to Profit from the New Power of Promotion Marketing”, 2nd ed., Dartnell Corp., Chicago, IL.

Wayne, M (2002) "Hitting your target with direct mail coupons" Marketing Magazine Vol. 107, No. 22, pp. 19-1/2p.

Zikmund, W.R. (1997) “Business Research Methods” (5th Ed.), Texas: The Dryden Press. 